of South Wales and Monmouthshire, takes to Cardiff his extensive experience in the fields of structure determination and synthesis. After spending most of the Second World War at Portsmouth Dockyard as a member of the Royal Naval Scientific Service and graduating in 1946 as an extermal student of the University of London, Dr. Crombie joined and became a leading member of S. H. Harper's research group at King's College, London, where he soon showed his outstanding qualities as a brilliant experimentalist. The fruitful collaboration with Harper in the field of pyrethrin chemistry continued for some years and laid the foundation for Dr. Crombie's continued interest in insecticidal substances of natural origin and in spectroscopic methods of structure determination, especially in relation to geometrical isomerism. These topics provide a thread of continuity for his more recent extensive researches on structure elucidation and synthesis of rotenoids and lipid isobutylamides. These investigations were carried out during periods on the teaching staff of the Imperial College of Science and Technology and King's College, where he has been reader in organic chemistry. Both in his researches and his activities as a teacher Dr. Crombie's work is characterized by intensive concentra. tion and by an elegant mastery of modern methods of organic chemistry.

\section{Chemistry in the University of Essex:}

Prof. J. N. Bradley

Dr. J. N. BradLey has been appointed to the chair of chemistry in the University of Essex, Colchester. Dr. Bradley, after graduating with honours in chemistry in the University of Birmingham, carried out research there for his Ph.D. degree under the supervision of Sir Harry Melville and Prof. J. C. Robb. In 1955 Bradley entered the Royal Air Force and served with 99 Squadron R.A.F. with the rank of Flying Officer. In August 1957 he was awarded a Commonwealth Fund fellowship tenable at Harvard University to work with Prof. G. B. Kistiakowsky until June 1959. Bradley was appointed lecturer in the Department of Inorganic and Physical Chemistry in the University of Liverpool in October 1959. At Harvard, Bradley became interested in reactions in shock waves, and with Prof. Kistiakowsky he developed a time of flight mass spectrometer which would analyse the gas behind the reflected shock wave while the reaction was proceeding. He applied this technique to investigations of pyrolysis and oxidation reactions. In Liverpool he continued his study of shock waves and built up an active research group. Bradley's present interests include the emission from shock-heated gases; the mechanism of thermal ionization in shock waves by mass-spectrometry, and the combination of flash photolysis and shock tube techniques. He has also maintained his early interest in the reactions of free radicals and the mass-spcetrometry of cool flames; and he is the author of a standard work entitled Shock Waves in Chemistry and Physics. Bradley was awarded the Meldola Medal in 1960 for his work on the kinetics and reactions involving active intermediates. Biochemistry at the Royal Free Hospital School of
Medicine, London:

DR. W. J. Whelan has been appointed to the new chair of biochemistry at the Royal Free Hospital School of Medicine, University of London, as from October 1. Dr. Whelan is a graduate of the University of Birmingham, holding the degrees of Ph.D (1948) and D.Sc. (1955). He was an assistant lecturer at Birmingham during 1947-48, and in 1948 transferred to the University College of North Wales, Bangor, with Prof. S. Peat, when the latter became professor of chemistry there. $\mathrm{He}$ served in Bangor until the end of 1955, becoming a senior lecturer in 1954, then transferring to his present post as a staff-member in the Department of Biochemistry at the Lister Institute. His earlier research work in Birmingham and Bangor, with Prof. Peat, coneerned the exploration of pathways of starch metabolism, and the application of modern chromatographic techniques to the study of polysaccharide struetures. In London he has been mainly concerned with the action patterns and substrate specificities of starch- and glycogen-metabolizing enzymes, and the knowledge gained earlier in regard to starch metabolism is now being applied to investigations of glycogen metabolism. New pathways of glycogenolysis have recently been recognized. Dr. Whelan has also been active in the affairs of the Biochemical Society, first as an editor of its Journal, as meetings secretary, and latterly as international secretary, and secretary of the Federation of European Biochemical Societies. Under his energetic direction, it can confidently be expected that an active school of biochemistry will develop at the Royal Free Hospital School of Medicine.

\section{Director of the National Institute of Agricultural Engineering: Mr. C.J. Moss}

Mr. C. J. Moss has been appointed to succeed Mr. W. H. Cashmore, as director of the National Institute of Agricultural Engineering, when Mr. Cashmore retires on July 31 , 1964. Mr. Moss was educated at Northgate School, Ipswich, and the University of London, where he obtained honours in mathematics and was awarded the Sir John William Lubbock Memorial Prize. During the Second World War, Mr. Moss worked in the aircraft industry and since then he has worked in the field of synthetic resin manufacture, with Imperial Chemical Industries Ltd., and was deputy director of the Central Engineering Establishment of the National Coal Board from 1958 until 1961, when he became assistant director-general in the Process Development Department of the National Coal Board.

\section{Collaboration between the U.S. House of Represen- tatives and the National Academy of Sciences}

Mr. GEORge P. MILler, chairman of the House Corn. mittee on Science and Astronautics, House of Representatives, Washington, D.C., has announced that he and Dr. Frederick Seitz, president of the U.S. National Academy of Sciences, in collaboration with Congressman Emilio Q. Daddario, chairman of the Sub-committee on Science, Research and Development, have agreed in principlo on the provision of certain services of the National Academy to the Committee. It should lead to a series of investigations worked out between panels of the Academy and tho Sub-committee. The arrangement with the House Committee grew from activitios of the Daddario Sub-committee, which has been seeking to identify the trouble spots in the Government-science relationship in order to evaluate better future Federal policies. Dr. Seitz, as a witness before the Sub-committee, has analysed services which the Academy might properly perform. The National Academy has been inereasingly concerned in recent years with tho interaction of science and public policy. It now has a prominent committee of its own exploring aspects of this question, a committee headed by Dr. George B. Kistiakowsky, of Harvard University, a former science adviser to the President.

From its beginnings (a hundrod years ago: Nature, 200, 396; 1963), the Acadomy has assisted in programmes which have helped the United States to move: into the top ranks of scientific achievement. These have included investigations ranging from problems of counter. feiting in 1866 to proservation of the Declaration of Independence in 1880, and to the International Ceo. physical Year of 1957-58, in which American scientists played a major part. The Academy's investigations have made important contributions to the establishment and growth of the United States Geological Survey, the Weather Bureau, the National Bureau of Standards and the Forest Service. Mr. Miller, eommenting on the new working arrangement, said that he believes the Academy, 